Provided for non-commercial research and education use. Not for reproduction, distribution or commercial use.

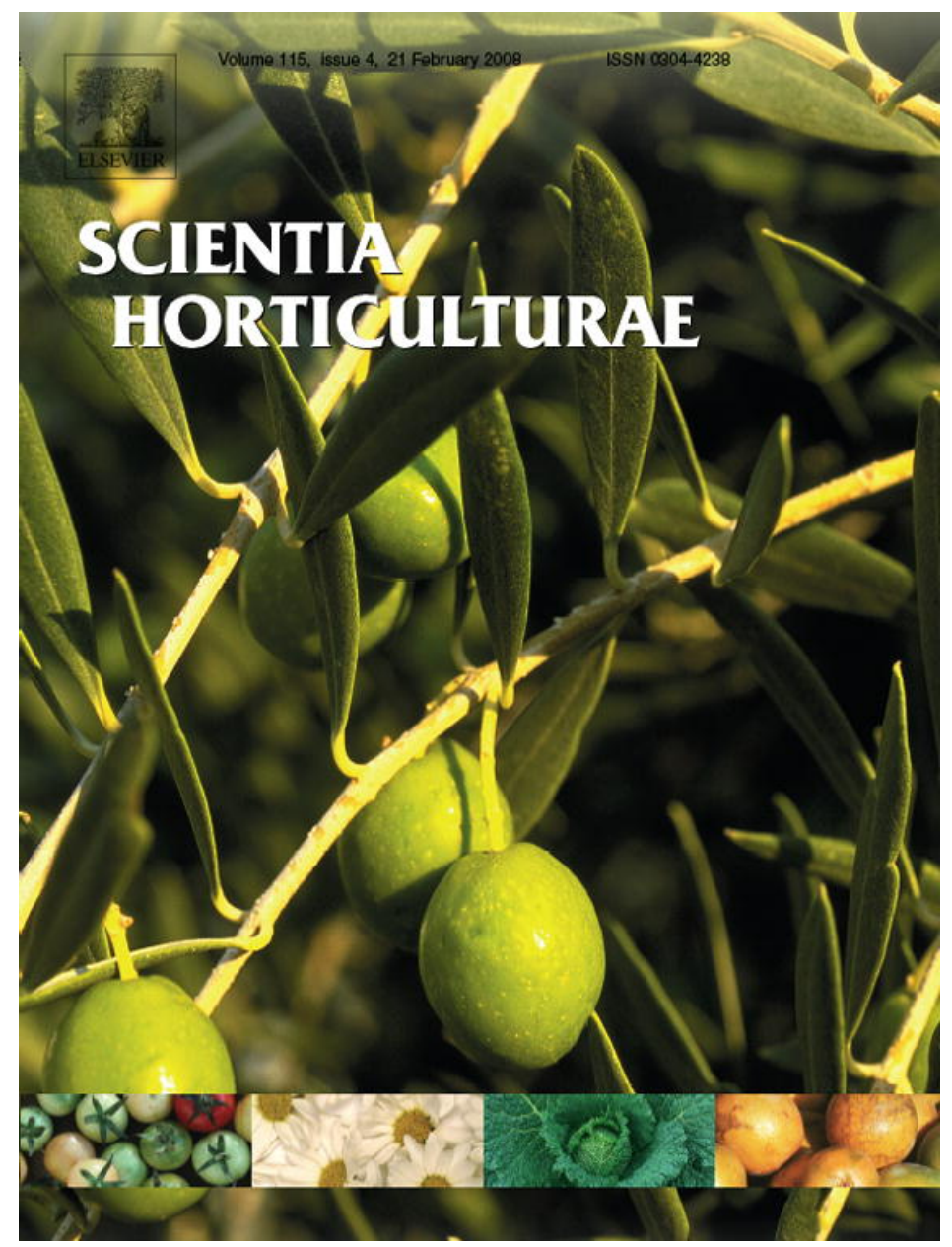

This article was published in an Elsevier journal. The attached copy

is furnished to the author for non-commercial research and education use, including for instruction at the author's institution, sharing with colleagues and providing to institution administration.

Other uses, including reproduction and distribution, or selling or licensing copies, or posting to personal, institutional or third party websites are prohibited.

In most cases authors are permitted to post their version of the article (e.g. in Word or Tex form) to their personal website or institutional repository. Authors requiring further information regarding Elsevier's archiving and manuscript policies are encouraged to visit: 


\title{
Genetic diversity in Tunisian olive accessions and their relatedness with other Mediterranean olive genotypes
}

\author{
Bchira Zitoun $^{\mathrm{a}, \mathrm{b}}$, Virginie Bronzini de Caraffa ${ }^{\mathrm{b}, *}$, Jean Giannettini ${ }^{\mathrm{b}}$, Catherine Breton ${ }^{\mathrm{c}}$, \\ Ahmed Trigui ${ }^{\mathrm{d}}$, Jacques Maury ${ }^{\mathrm{b}}$, Claude Gambotti ${ }^{\mathrm{b}}$, Brahim Marzouk ${ }^{\mathrm{a}}$, Liliane Berti ${ }^{\mathrm{b}}$ \\ a I.N.R.S.T. Tunis, BP 95, 2050 Hamman-Lif, Tunisia \\ ${ }^{\mathrm{b}}$ Université de Corse, UMR-CNRS 6134, BP 52, 20250 Corte, France \\ ${ }^{\mathrm{c}}$ Université de Montpellier 2, UMR 5171, 34200 Sète, France \\ ${ }^{\mathrm{d}}$ Institut de l'Olivier, BP 1087, 3000 Sfax, Tunisia
}

Received 16 February 2007; received in revised form 28 September 2007; accepted 17 October 2007

\begin{abstract}
Eighty-four olive accessions obtained from the National Conservatory of Boughrara-Sfax (Tunisia), previously evaluated for morphological traits, were analysed with 47 random amplified polymorphic DNA (RAPD) markers. They were compared with other olive genotypes originated from Eastern or Western Mediterranean. The highest and lowest similarities between genotypes, estimated by simple matching algorithm, were 0.98 and 0.40 , respectively. A dendrogram based on Ward's method and a factorial correspondence analysis (FCA) showed that most of Tunisian accessions are closely related to olive genotypes originating from the Eastern Mediterranean and some are clustering with genotypes originated from the Western Mediterranean. These findings suggested multiple and complex origin of Tunisian olive. A comparative study between a previous morphological analysis and current RAPD assay was carried out and discussed.
\end{abstract}

(C) 2007 Elsevier B.V. All rights reserved.

Keywords: Olea europaea L.; Morphology; RAPD (random amplified polymorphic DNA)

\section{Introduction}

Olive (Olea europaea L. subsp. europaea var. europaea) has been domesticated by 5800 B.P. (Zohary and Hopf, 1994) probably both in Eastern and Western of the Mediterranean basin (Besnard and Bervillé, 2000). The cultivated olive $(O$. europaea L. var. europaea) is propagated by cutting or grafting, whereas wild olive (O. europaea L. var. sylvestris) reproduced from seeds (Green, 2002). These two olive types are interfertile and have led to a large number of varieties. The official key for identification of varieties is based on morphological criteria (Barranco and Rallo, 1984; Prevost et al., 1993) although they are influenced by environmental conditions. However, molecular markers, as random amplified polymorphic DNA (RAPD) markers, are environment-independent and efficient to identify olive varieties and to detect synonymous and homonymous

\footnotetext{
* Corresponding author. Tel.: +33 495450066; fax: +33 495450180.

E-mail address: bronzini@univ-corse.fr (V. Bronzini de Caraffa).
}

(Fabbri et al., 1995; Besnard et al., 2001a; Bronzini de Caraffa et al., 2002a).

In Tunisia, olive cultivation is of great socio-economic importance with more than 60 millions of olive trees including a wide range of olive denominations. The major part of Tunisian olive germplasm has been gathered in a collection located in the "National Conservatory of Boughrara-Sfax". This germplasm has been characterized previously with morphological criteria (Mehri et al., 1997; Trigui et al., 2006).

In the present study, we have analysed Tunisian olive accessions from this collection and olive genotypes originating from the East and the West of the Mediterranean, using RAPD technology. A comparison of morphological and molecular groups was also performed to investigate the usefulness of molecular markers as a supplement, a complement and/or an alternative for varietal distinctness based on morphological criteria. The feasibility of varietal identification based on RAPD data entirely or in combination with traditional morphological evaluation is discussed. 


\section{Material and methods}

\subsection{Plant material}

Eighty-four olive accessions collected from Tunisia and conserved in the olive germplasm collection of Boughrara-Sfax (Tunisia) were included in this study. Unknown accessions were labelled with a common name "Local type" and referenced with a code number. Out of these 84 accessions, 65 have been previously differentiated by morphological criteria which are 10 endocarp criteria (Trigui, personal communication).

Foreign olive material (13 from the East and 5 from the West of the Mediterranean basin) was also included in this study. Their geographical origin has been previously determined using mitochondrial DNA (Besnard et al., 2001b; Bronzini de Caraffa et al., 2002b).

\subsection{DNA extraction and RAPD analysis}

Total DNA extraction was performed as described by Saghai-Maroof et al. (1984) with some modifications (Bronzini de Caraffa et al., 2002a). PCR amplifications were performed with a thermal cycler (PerkinElmer, USA) using eight decamerprimers (Eurogentec, Belgium, Kits A, C, D and O) (A1, A2, A9, A10, A19, C15, O8 and O15) as described by Bronzini de Caraffa et al. (2002a). Amplification products were analysed by electrophoresis through 1.6\% Agarose (Eurogentec) followed by ethidium bromide staining. Size of fragments was estimated using the $1 \mathrm{~Kb}$ DNA ladder (Promega, USA). The amplification reactions were repeated at least twice and only reproducible and intense bands were scored.

\subsection{Data record and analyses}

RAPD bands were scored as 1 (band present) or 0 (band absent). Simple matching algorithm (Sokal and Michener, 1958) was used to estimate genetic similarities between each pair of individuals and to construct a dendrogram with Ward's minimum variance method (Ward, 1963). This method considered RAPD bands as phenotypic rather than genetic characters. Similarity matrix and cluster algorithms were carried out using the program developed by J. Brzustowski (http://www2.biology.ualberta.ca/ jbrzusto/cluster.php). In addition, the RAPD data were analysed by factorial correspondence analysis (FCA) using the GENETIX package, version 4.04 .

\section{Results and discussion}

A total of 58 bands, ranging in size from 230 to $1900 \mathrm{bp}$, were scored with the eight primers, and 47 were polymorphic and reproducible $(81 \%)$. They allowed to discriminate the 18 foreign olives and 57 Tunisian olive accessions among the 84 studied. The accessions having the same RAPD profiles were different with morphological assay based on endocarp criteria. Therefore, 19 accessions, not discriminated by morphological criteria, were clearly discriminated by the RAPD analysis:
Chemchali and Local type 1; Chemlali 5 and Local type 22; Dhokkar and Local type 8; Chetoui 1, Chetoui 2 and Local type 7; Local type 35 and Local type 36; Local type 32, Local type 34, Local type 37 and Local type 39; Local type 13 and Local type 14; Local type 48 and Local type 56 (Trigui, personal communication). Differences in results obtained by molecular and morphological approaches were reported in other species as pomegranate (Sarkhosh et al., 2006). A reason is that marked morphological differences between accessions did not necessarily translate to marked differences in RAPD phenotypes. Morphological and RAPD analysis were two phenotypic methods which could be combined for varietal identification.

Similarity values ranged from 0.40 (East 13 and Chemlali 5; West 1 and Local type 6) to 0.98 (several pairs of individuals such as Local type 41 and Local type 46 or Local type 11 and Local type 54) with an average of 0.73 . The results showed that the best agreement between the morphological and RAPD analysis was obtained for accession pairs with a low similarity coefficient. For closely related accessions, the use of other molecular markers such as microsatellites providing a much more improved analysis, may explore differences between them (Diaz et al., 2006).

In the Ward's dendrogram, the olive trees were separated in two main branches (Fig. 1). The branch 1 included 54/84 Tunisian accessions and all of East and West genotypes studied. This group was separated into three subgroups (1.1, 1.2 and 1.3). There was less Jacknife support for both clusters $1.1(38 \%)$ and $1.2(26 \%)$ than for $1.3(74 \%)$. This indicates that accessions belonging to these clusters were not well discriminated by RAPDs. Cluster 1.1 included 17 Tunisian accessions (10 from the South and 7 from the North of the country) and the Eastern genotypes. Cluster 1.2 consisted of Tunisian accessions from the South except Local type 7, Chetoui 1 and Chetoui 2. Cluster 1.3 contained three Tunisian accessions from Sfax (South of Tunisia) (Local types 36, 35 and 44) with the five Western accessions. Branch 2 consisted exclusively of Southern Tunisian accessions except two from the North of Tunisia.

Three clouds were obtained by FCA analysis (Fig. 2) and the first three axes explained $31.15 \%$ of the total variability. The FCA pattern was comparable to the clustering pattern in the dendrogram with some exceptions. The group on the right contained the Tunisian accessions grouped in the branch 2 on the dendrogram except Local type 5. All these accessions are originating of the Southern Tunisia what suggested an autochthonous origin as well as their limited diffusion from their centres of origin (Besnard et al., 2001b; Belaj et al., 2003). In the cloud on the centre (cluster 1.1 and 1.2 on the dendrogram, except Local type 42 and Chemlali 5, and Local type 56), 49 out of 84 Tunisian accessions were more similar to the Eastern genotypes those from their own country. The last cloud, on the left, contained the three Tunisian accessions and the five Western genotypes grouped together in the cluster 1.3 on the dendrogram. These results showed a clear cut-separation between genotypes from the East and those from the West. These findings were in accordance that the selection of olive cultivars occurred in different genetic pools in the East and West of the Mediterranean (Besnard and Bervillé, 2000; Terral 


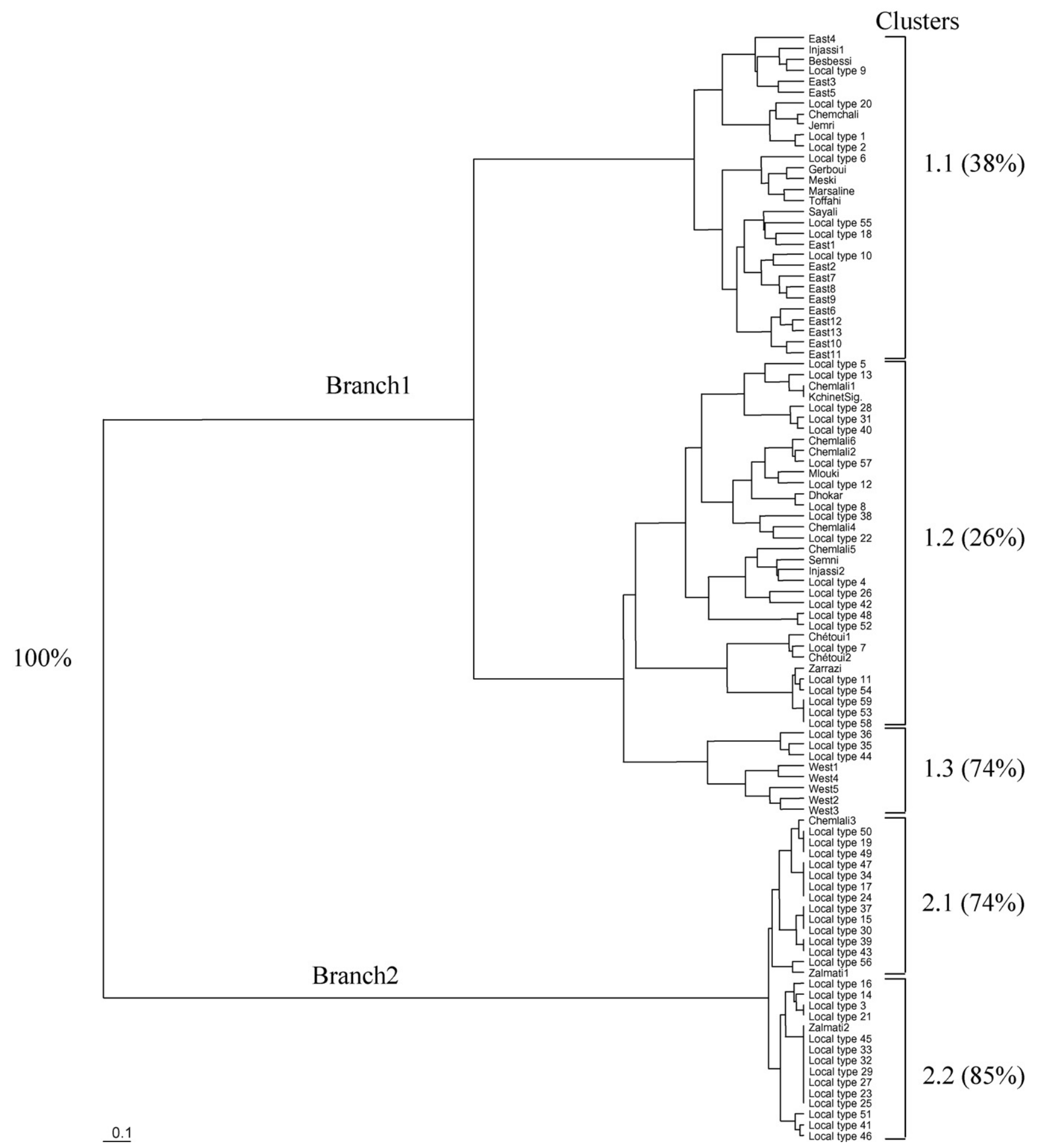

Fig. 1. Dendrogram using Ward's clustering method of the 102 olive individuals. Support for branching pattern was determined using Jacknife approach. Branch 1 consisted of clusters $1.1,1.2$ and 1.3 .

et al., 2004). They suggested multiple and complex origin of Tunisian olive. A clustering of olive varieties from different geographic origins had also been observed in other studies performed with molecular markers (Bronzini de Caraffa et al., 2002a; Belaj et al., 2003; Owen et al., 2005). Such clustering patterns showed that some Tunisian accessions might have been introgressed by olives from the Eastern Mediterranean. Plant material interchange and crossings might have occurred through the history.

The genetic variability detected among Tunisian accessions could be of major importance for solving problems concerning the management of the Tunisian olive germplasm. The overall findings were that enough genetic diversity could be detected, from the comparative study of molecular and morphological 


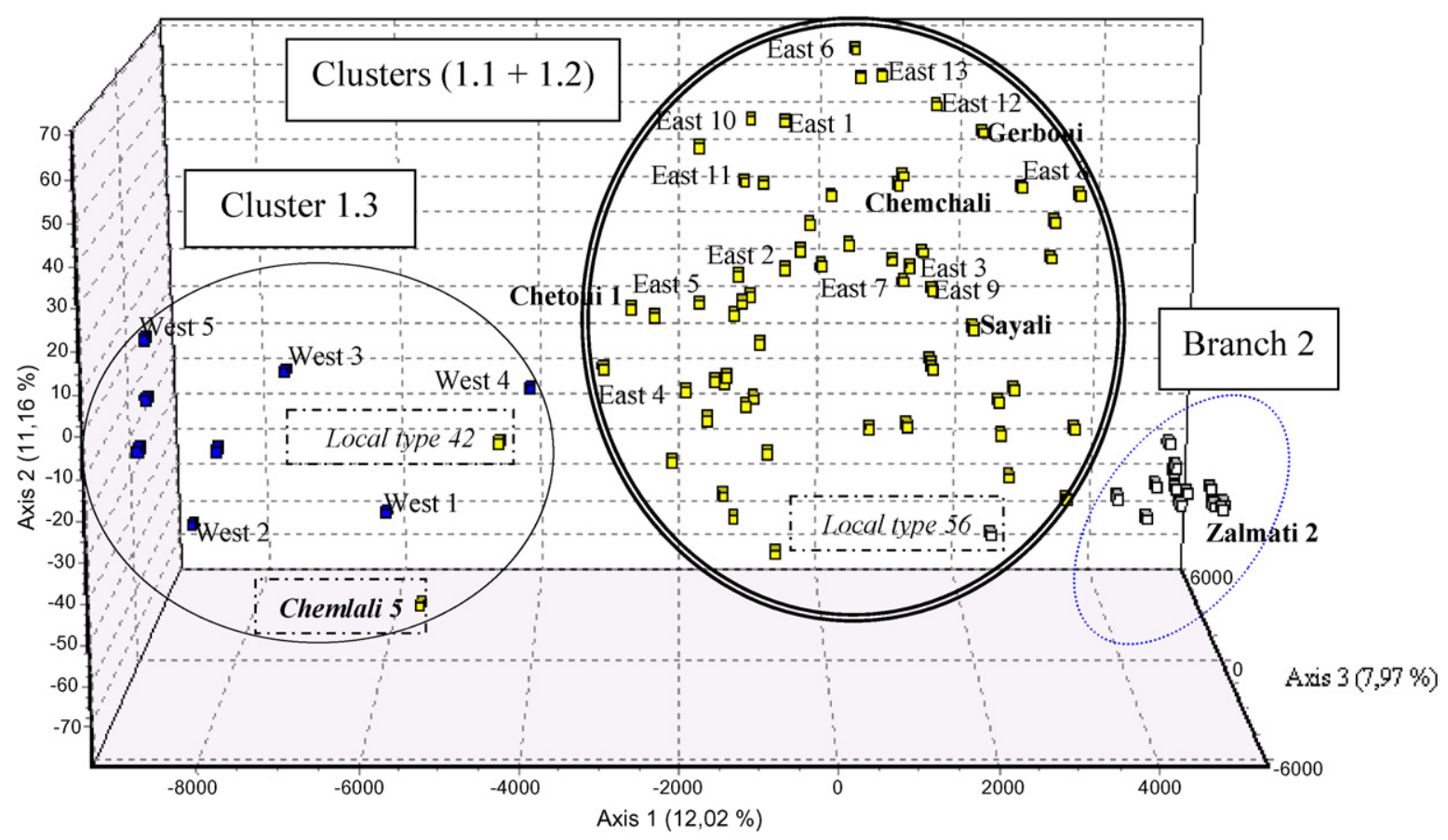

Fig. 2. Factorial correspondence analysis based on RAPD data. The exceptions (accessions not clustered as in the dendrogram) are indicated by their names in italic.

approaches, using RAPD markers combined with morphological criteria, to differentiate registered olive varieties. This may help to the registration of new varieties which could be of a great interest for breeders. However, to construct a molecular data base that can be used to make a reference collection, more primers and preferably other markers such as microsatellites may be necessary and should be compared with the present assay.

\section{Acknowledgements}

We thank the Collectivite Territoriale de Corse for supporting this study. We are also grateful to Dr. A Bervillé for fruitful discussions.

\section{References}

Barranco, D., Rallo, L., 1984. Las variedades de olivo cultivadas en Andalucia Consejeria de la Junta de Andalucia. MAPA, Madrid.

Belaj, A., Satovic, Z., Ismaili, H., Panajoti, D., Rallo, L., Trujillo, I., 2003. RAPD genetic diversity of Albanian olive germplasm and its relationships with other Mediterranean countries. Euphytica 130, 387-395.

Besnard, G., Baradat, P., Bervillé, A., 2001b. Genetic relationships in the olive (Olea europaea L.) reflect multilocal selection of cultivars. Theor. Appl. Genet. 102, 251-258.

Besnard, G., Bervillé, A., 2000. Multiple origins for Mediterranean olive (Olea europaea L. subsp europaea) based upon mitochondrial DNA polymorphisms. CR. Acad. Sci. Paris série III 323, 173-181.

Besnard, G., Breton, C., Baradat, P., Khadari, B., Bervillé, A., 2001a. Cultivar identification in olive based on RAPD markers. J. Am. Soc. Hort. Sci. 126, 668-675.

Bronzini de Caraffa, V., Giannettini, J., Gambotti, C., Maury, J., 2002a. Genetic relationships between cultivated and wild olives of Corsica and Sardinia using RAPD markers. Euphytica 123, 263-271.

Bronzini de Caraffa, V., Maury, J., Gambotti, C., Breton, C., Bervillé, A., Giannettini, J., 2002b. Mitochondrial DNA variation and RAPD mark oleasters, olive and feral olive from Western and Eastern Mediterranean. Theor. Appl. Genet. 104, 1209-1216.

Diaz, A., De la Rosa, R., Martin, A., Rallo, P., 2006. Development, characterization and inheritance of new microsatellites in olive Olea europaea L.) and evaluation of their usefulness in cultivar identification and genetic relationship studies. Tree Genet. Genom. 2, 165-175.

Fabbri, A., Hormaza, J.I., Polito, V.S., 1995. Random amplified polymorphic DNA analysis of olive (Olea europaea L.) cultivars. J. Am. Soc. Hort. Sci. $120,538-542$.

Green, P.S., 2002. A revision of Olea L. (Oleaceae). Kew Bull. 57, 91-140.

Mehri, H., Msallem, M., Kamoun Mehri, R., 1997. Identification des principaux cultivars d'oliviers cultivés en Tunisie. Plant. Genet. Res. Newslett. 112, 68-72.

Owen, C.A., Bita, E.C., Banilas, G., Hajjar, S.E., Sellianakis, V., Aksoy, U., Hepaksoy, S., Chamoun, R., Talhook, S.N., Metzidakis, I., Hatzopoulos, P., Kalaitzis, P., 2005. AFLP reveals structural details of genetic diversity within cultivated olive germplasm from the Eastern Mediterranean. Theor. Appl. Genet. 110, 1169-1176.

Prevost, G., Bartolini, G., Messeri, C., 1993. Cultivar italiane di olivo e loro sinonimi. Menegazzo, Lucca.

Saghai-Maroof, M.A., Solinam, K.M., Jorgensen, R.A., Allerd, R.W., 1984. Ribosomal DNA spacer length polymorphisms in barley: Mendelian inheritance, chromosomal location and population dynamics. Proc. Natl. Acad. Sci. USA 81, 8014-8018.

Sarkhosh, A., Zamani, Z., Fatahi, R., Ebadi, A., 2006. RAPD markers reveal polymorphism among some Iranian pomegranate (Punica granatum L.) genotypes. Scientia Hort. 111, 24-29.

Sokal, R.R., Michener, C.D., 1958. A statistical method for evaluating systematic relationships. Univ. Kansas Sci. Bull. 38, 1409-1438.

Terral, J.F., Alonso, N., Capdevila, R.B., Chatti, N., Fabre, L., Fiorentino, G., Marinval, P., Pérez Jordá, G., Pradat, B., Rovira, N., Alibert, P., 2004. Historical biogeography of olive domestication (Olea europaea L.) as revealed by geometrical morphometry applied to biological and archaeological material. J. Biogeogr. 31, 63-77.

Trigui, A., Yengui, A., Belguith, H., 2006. Olive germplasm in Tunisia. Olea 25, 19-23.

Ward Jr., J.H., 1963. Hierarchical grouping to optimize an objective function. J. Am. Stat. Assoc. 58, 236-244.

Zohary, D., Hopf, M., 1994. Domestication of Plants in the Old World, second ed. Clarendon Press, Oxford. 